\title{
GÉPKOCSI KERÉKFELFÜGGESZTÉSEK REZGÉSI TULAJDONSÁGAINAK SZIMULÁCIÓJA ÉS MÉRÉSE
}

\section{ANALYSIS OF VIBRATION STATES OF CARS BY EXPERIMENTAL MEASUREMENTS AND DYNAMICAL MODEL SIMULATIONS}

\author{
Varga István ${ }^{1}$, Dezső Gergely ${ }^{2}$ \\ ${ }^{I}$ Nyíregyházi Főiskola Müszaki és Agrártudományi Intézet Cím: Magyarország, \\ 4400 Nyirregyháza Sóstói út 31/b. Telefon / Fax: $+3620599400 / 2442$, levelezési cím, \\ dezsog@nyf.hu \\ ${ }^{2}$ Nyíregyházi Föiskola Müszaki és Agrártudományi Intézet Cím: Magyarország, \\ 4400 Nyíregyháza Sóstói út 31/b. Telefon / Fax: $+3620599400 / 2442$, levelezési cím, \\ vargaistvan.rs@gmail.com
}

\begin{abstract}
Car suspension systems were investigated experimentally on a shock absorber test bench and theoratically by simulation. It is demonstrated that results of the model shows quantitative agreement with experimental measurements.

Keywords: quarter model, car suspension system, vibration.

\section{Összefoglalás}

Személygépkocsik kerékfelfüggesztésének rezgési tulajdonságait vizsgáltam lengéscsillapító próbapadon méréssel, valamint számítógépes szimulációval. Sikerült olyan számítógépes modellt felépíteni, amely jó kvantitatív egyezést mutat a kísérleti eredményekkel.
\end{abstract}

Kulcsszavak: negyedmodell, kerékfelfüggesztés, rezgés.

\section{Bevezetés, célkitűzés}

A jármüdinamika olyan kérdésekkel foglalkozik, amelyek alapjaiban határozzák meg egy gépjármü menettulajdonságait, biztonságát és használóinak kényelemérzetét [1]. A jármügyártók folyamatosan fejlesztik a futóműveket, ezért a dinamikai mennyiségek mérése igen fontos kérdés $[2,3]$.

A gépjármü a szükebb mechanikai szempontból is, és tágabb értelemben is egy összetett dinamikai rendszer [4]. Müködésének modellezésére matematikai eszközök is rendelkezésre állnak. Az elmúlt néhány évtizedben az informatika rohamos fejlödésének köszönhetően a számítógépes szimuláció a kutatás-fejlesztésben hatékony és egyre szélesebb körben elérhető eszközzé vált $[5,6]$.

Célkitüzésünk személygépjárművek rezgéseinek mérése lengéscsillapító vizsgáló próbapadon történő gerjesztés során, két gépjármü esetén, a keréknyomás változtatásával. 


\section{A harmonikus analízis, az FFT}

Ha az általunk vizsgált folyamat szigorúan periodikus és (elméletileg) végtelen ideig tart, akkor Fourier tétele szerint megadható az alábbi alakban:

$x(t)=\sum_{k=1}^{\infty}\left[c_{k} \cdot \sin \left(k \omega_{0} \cdot t\right)-d_{k} \cdot \cos \left(k \omega_{0} \cdot t\right)\right]$

A valóságban a legtöbb folyamatnak nincs szigorú periodicitása, és időben végesek (lásd: 1. ábra).

Ebben az esetben az $x(t)$ függvény előállítása:

$$
x(t)=\int_{-\infty}^{\infty} c(\omega) e^{i \omega t} d \omega
$$

ahol $c(\omega)$ a valós számok halmazán értelmezett folytonos függvény, az $x(t)$ Fourier-transzformáltja.

A $c(\omega)$ Fourier-transzformált elöállítása:

$$
c(\omega)=\int_{-\infty}^{\infty} x(t) e^{-i \omega t} d \omega
$$
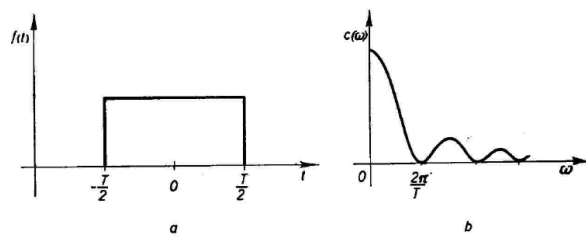

1. ábra: Nem periodikus négyszögimpulzus

A diszkrét Fourier-transzformáció (DFT) egy függvény egyenközü mintavételezésével kapott, véges számosságú adatsort alakít át szinusz függvények olyan lineáris kombinációjává, amelynek helyettesítési értékei megegyeznek a mintával.

A gyors Fourier-transzformáció (fast Fourier-transform, FFT) olyan algoritmus, amely a diszkrét Fourier-transzormáció hatékony kiszámítására szolgál. Az FFT a diszkrét Fourier-transzformáció N2 -tel arányos müveletigényét $\mathrm{N} \log 2 \mathrm{~N}-$ nel arányosra csökkenti, így teszi azt gyorsabbá [7].
A mintavételezés jelentősen befolyásolja az FFT hatékonyságát. $N=2^{n}$ egyenközü mintavétel szükséges, ahol $n \geq 6$. A mintavételezés frekvenciáját úgy választjuk meg, hogy legalább kétszerese legyen a maximális vizsgálandó frekvenciának, ellenkező esetben a mintavételezés pontossága bizonytalan.

\section{A mérés}

A választott gerjesztő berendezés egy pusztadobosi üzemben található, a személyautók időszakos hatósági vizsgáztatásához használt Weszti-Kontrol személygépkocsi fék- és lengéscsillapító vizsgáló berendezés lett. A szerkezet lengésvizsgáló része EUSAMA-rendszerü, $24 \mathrm{~Hz}$-es induló gerjesztő frekvenciával és 3 milliméteres amplitúdóval müködik. A müszer a kerék által a talajra kifejtett erőt („talpnyomás”), és annak minimumát vizsgálja a gerjesztő frekvencia 0-tól $24 \mathrm{~Hz}$-ig terjedő tartományában.

A rezgésmérést Sinus Soundbook típusú berendezéssel végeztük [8]. Ennek fö részei:

- Piezoelektromos szenzor és ezt a panellel összekötő vezetékek (2. ábra);

- Sinus Soundbook moduláris panel;

- Panasonic Toughbook CF-19 laptop;

- Samurai 2.0 rezgés- és zajmérő szoftver.

A program, amely segítségével a mérési folyamat és a kiértékelés kontrollálható, a Samurai 2.0, melyet kifejezetten zaj- és rezgésdiagnosztikai vizsgálatokhoz fejlesztettek.

A rezgésértékeket 0 és $20000 \mathrm{~Hz}$ közötti frekvenciatartományokban képes megjeleníteni és rögzíteni. A program segítségével a rögzített időbeli jelenség gyors Fouriertranszformációval frekvencia tartományba transzformálható, ami segíti a mérési eredmények elemzését.

A mérések alkalmával az egyik tengelylyel ráálltunk a gerjesztő talpakra. 
Az érzékelőt ragasztó segítségével rögzítettük a kerékanyán, a karosszéria fém sárvédő elemén és a gerjesztő lapon egyaránt.

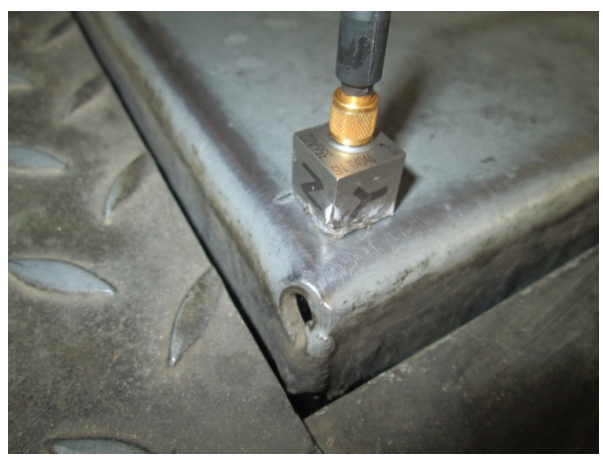

2. ábra: A gerjesztő berendezés mérése

Megállapítottuk, hogy a gerjesztési ciklus 13 másodperc terjedelmü, ezért a mérési intervallumot 15 másodpercnek választottuk. A mérések végrehajtásához két jármüvet használtunk fel: egy 2005-ös évjáratú, lineáris rugózású Suzuki Ignist és egy 1992es, progresszív hátsó futómüves BMW E30ast.

\section{A modell}

A modell megépítéséhez (3. ábra) a valós jármüből a következő adatokat használtuk fel:

- A futóművek karakterisztikái

- Jármüvek tömege, méretjellemzöi

- Gerjesztés adatai (frekvencia, amplitúdó)

Ezeket az információkat a fentebb leírtak alapján a mérések során határoztuk meg.

Modellünk megértéséhez érdemes az alkatrészeket szintekre osztani:

- Térben rögzített kocka (a képen átlátszó)

- Talaj kockái

- A kerekeket és a járulékos tömegeiket helyettesítö testek
- A kerekeket és a karosszériát összekötő kereszt-lengőkarok (futómüvenként 2 darab)

- Jármü felépítmény

Az építés során a talajt és a térben rögzített testet pozícionáltam elöször. A talaj kockái közül egyet nem rögzítettem, hiszen ezen keresztül kapta a jármü a gerjesztést, a többit a referenciatesttel együtt térben rögzítettem a korábban meghatározott helyükön.

A jármü kerekeit és felépítményét egyszerü negyedmodellként konstruáltam, majd ezt két lépésben tükrözve kaptam meg a teljes autómodellt.

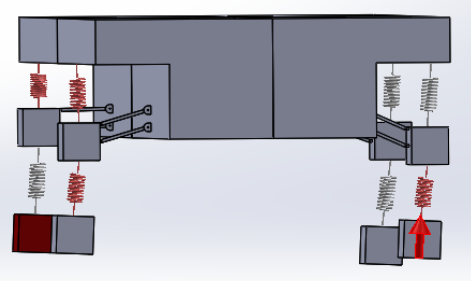

3. ábra: A dinamikai modell a gerjesztési folyamat közben

\section{Eredmények összehasonlítása}

A szimuláció során másodpercenként 200 mintát vettük, így a 2 másodpercnyi gerjesztés 400 adatot eredményezett. Megjelenítésére a Scope DSP 5.0 nevü szoftvert hívtuk segítségül (4. ábra).

A mért adatokat az 5. ábrán látható módon a Samurai programból exportáltuk ki Excel formátumban.

Az amplitúdóbeli eltérések a csillapítás paraméter illesztés elötti állapotának köszönhetők, hiszen magát a csillapítást nem tudtuk pontosan megmérni. Viszont ahogyan a 6. ábra is mutatja, megfelelően illesztett csillapítással igen nagy hasonlósá- 
got tapasztalunk az eloszlás és az amplitúdók terén is.

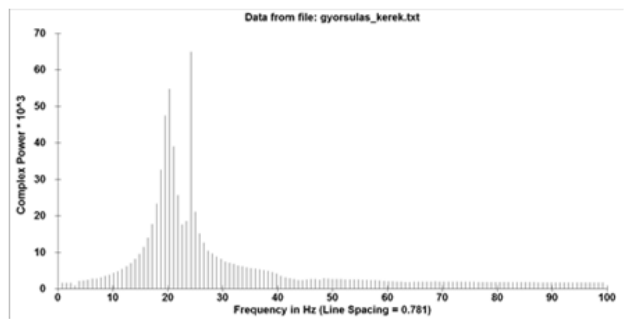

4. ábra: Suzuki Ignis-modell kerekének FFT-je

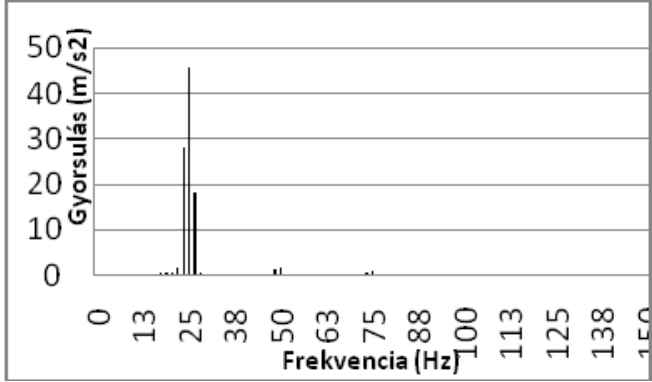

5. ábra: Suzuki Ignis kerekének mért FFT-je

\section{Következtetések}

A mérések eredményei visszaigazolták a szimulációs eredmények a használhatóságát. A karosszéria rezgései, mivel mi a modell felépítményét monolit szerkezetként konstruáltuk, az összehasonlításhoz zajosak voltak.

Megállapítottuk, hogy a gyorsulás-idő függvények felhasználhatósága éppúgy helytálló, mint a kitérés-idő függvények esetében.

A BMW hátsó tengelyén, bár progreszszív rugókat találunk, a megfelelő méretezésének köszönhetően a vizsgálat során nem tapasztaltunk nemlineáris viselkedést

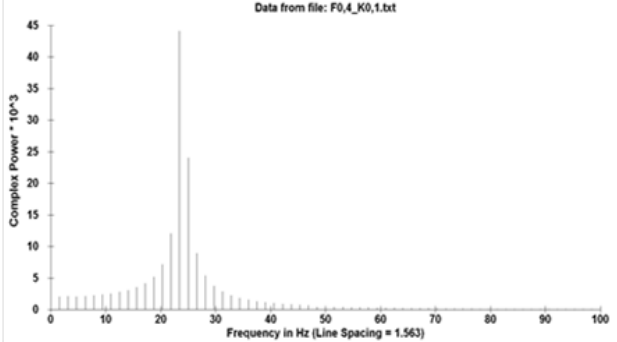

6. ábra: Suzuki Ignis-modell kerekének FFT-je paraméter-illesztett csillapítással

Kimutattuk, hogy a szimulációval kapott gyorsulás-idő függvény frekvencia tartományban igen jó egyezést mutat a méréssel kapott gyorsulás-idő függvénnyel.

Mindezek után elmondható, a többtest szimuláció a gépjárművek vertikális dinamikai tulajdonságait jól írja le, ezért hatékony eszköz lehet a tervezés folyamatában.

\section{Szakirodalmi hivatkozások}

[1] Zomotor Ádám: Gépjármü menetdinamika, Maróti Könyvkereskedés és Könyvkiadó Kft., Budapest, 2006, ISBN 9632124006

[2] Mike Blundell, Damian Harty: The multibody systems approach to vehicle dynamics, Elsevier Butterwort-Heinemann, 2004, ISBN 0750651121

[3] Giancarlo Genta: Motor vehicle dynamics, modeling and simulation, World Scientific Publishing Co., 2006, ISBN 9810229119

[4] Varga, I., Dezső, G.: Kerékfelfüggesztések mozgásának dinamikai vizsgálata személygépkocsiknál, Nyíregyházi Főiskola, TDK dolgozat, 2013.

[5] Wilfried Staudt: Gépjármütechnika, „OMÁR” Könyvkiadó, Székesfehérvár, 1988, ISBN 9638510803

[6] Dukkipati, V. R. et al. (2008): Road Vehicle Dynamics. SAE International, ISBN 978-07680-1643-7

[7] Cooley, J. W., Tukey, O. W.: An Algorithm for the Machine Calculation of Complex Fourier Series, Math. Comput. 19, 297-301, 1965.

[8] Samurai 2.0 Manual, Sinus Messtechnik $\mathrm{GmbH}, 2011$ 